\title{
PENINGKATAN KETERAMPILAN BERBICARA SISWA MELALUI MODEL PEMBELAJARAN PICTURE AND PICTURE DI KELAS 5 SD NEGERI MANGUNSARI O3 SALATIGA
}

\author{
Febry Damai Riyanti
}

Surel: 292013262@ student.uksw.edu

\begin{abstract}
This study aims to determine the improvement of students' speaking skills by using the picture and picture model in grade V SD Negeri Mangunsari 03 Salatiga. This type of research is Classroom Action Research. Data analysis technique used is descriptive qualitative data analysis supported by quantitative data. The results of data analysis showed an increase after after the action. This is apparent in the result of comparison between the average score on prasiklus of 19.97, the average score in cycle I increased by 3.36 to 23.33. The average score in cycle II increased by 2.84 to 26.17. The overall increase from prasiklus to cycle II is 6.2.
\end{abstract}

Keywords: Model Picture And Picture, Speech Skills

\begin{abstract}
ABSTRAK
Penelitian ini bertujuan untuk mengetahui peningkatan keterampilan berbicara siswa dengan menggunakan model picture and picture pada siswa kelas V SD Negeri Mangunsari 03 Salatiga. Jenis penelitian ini adalah Penelitian Tindakan Kelas. Teknik analisis data yang digunakan adalah analisis data diskriptif kualitatif yang di dukung data kuantitatif. Hasil analisis data menunjukkan terjadi peningkatan setelah setelah dilakukannya tindakan. Hal ini Nampak pada hasil berbandingan antara skor rata-rata pada prasiklus sebesar 19.97, skor rata-rata pada siklus I meningkat sebesar 3.36 menjadi 23.33. sekor rata-rata pada siklus II mengalami peningkatan sebesar 2.84 menjadi 26.17. Peningkatan keseluruhan dari prasiklus sampai dengan siklus II sebesar 6.2.
\end{abstract}

Kata Kunci: Keterampilan Berbicara, Model Picture And Picture.

\section{PENDAHULUAN}

Berbicara merupakan salah satu dari empat aspek keterampilan berbahasa yang sangat penting dimiliki dan dikuasai oleh seseorang. Bahkan keberhasilan seseorang, misalnya dalam meniti karir hal tersebut dapat juga ditentukan oleh terampil atau tidaknya seseorang dalam berbicara. Untuk itulah, sudah seharusnya di sekolah-sekolah terutama sekolah dasar, membekali peserta didik dengan memperbanyak latihan-latihan keterampilan berbicara. Bloom field, mengungkapkan bahwa semua aktivitas manusia yang terencana didasarkan pada bahasa. Bahasa

Jurusan PGSD FKIP Universitas Kristen Satya Wacana 
sendiri mempunyai bentuk dasar berupa ucapan atau lisan jadi jelas bahwa belajar bahasa pada hakikatnya adalah belajar berkomunikasi, dan komunikasi itu adalah berbicara.

Namun, pencapaian

kompetensi keterampilan berbicara pada umumnya belum maksimal, karena beberapa faktor yang menjadi penyebab, salah satunya adalah model pembelajaran atau media pembelajaran. Penerapan model pembelajaran yang tepat dalam kegiatan belajar mengajar, diharapkan akan mampu meningkatkan keterampilan berbicara siswa.

Hasil wawancara terhadap guru kelas dan observasi yang dilakukan saat Praktik Kerja Nyata (PPL) SDN Mangunsari 03 Salatiga kelas 5, diperoleh bahwa pada umumnya proses pembelajaran Bahasa Indonesia, khususnya aspek berbicara kurang maksimal. Hal ini terbukti ketika proses pembelajaran berlangsung siswa siswa masih pasif, tidak mau bertanya, diam saja, dan jika guru meminta berbicara siswa masih terbata-bata dan malu, dan masih ragu-ragu untuk menjelaskan atau menceritakan materi yang diajarkan. Keterampilan berbicara yang rendah juga dapat dilihat ketika guru memberikan sebuah soal dengan jawaban siswa berbicara di depan kelas, dari 38 siswa barulah 17 siswa yang berani maju berbicara di depan kelas tanpa paksaan oleh gurunya. Mereka sudah cukup baik dalam berbicara. Mereka sudah memperhatikan aspek-aspek berbicaranya seperti keberanian, sikap, dan tekanan suaranya. Sementara itu, 21 siswa yang lainnya, ketika diminta maju ke depan untuk berbicara masih takut, dan malumalu, harus dipaksa oleh gurunya. Dengan dipanggil beberapa kali, barulah siswa tersebut mau maju berbicara di depan kelas. Namun siswa-siswa tersebut, ketika berbicara, masih asal dan belum memperhatikan aspek berbicaranya. Hal tersebut menjadikan nilai keterampilan berbicara siswa di SDN Mangunsari 03 tergolong rendah.

Rendahnya nilai keterampilan berbicara dapat dilihat nilai rerata siswa dalam keterampilan berbicara siswa SDN Mangunsari 03 yaitu 19,97 atau sebesar $45 \%$. Nilai rerata tersebut belum memenuhi rerata ketuntasan minimal yaitu 23.00 atau sebesar $61 \%$. Dengan memahami hal tersebut, dapat diketahui bahwa siswa kelas 5 SDN Mangunsari 03 masih belum memiliki keterampilan berbicara dan masih sulit mengomunikasikan informasi yang didapatnya.

Bahasa merupakan alat
komunikasi antar anggota
masyarakat. Keraf (1987) menyatakan
bahwa bahasa adalah alat komunikasi
anggota masyarakat yang berupa
lambing bunyi suara yang dihasilkan
oleh alat ucap manusia. Pendapat ini
didukung oleh Wujosoedamono


(1983) menyatakan bahwa bahasa adalah alat komunikasi antar anggota masyarakat, yang berupa bunyi suara atau tanda/isyarat atau lambing yang dikeluarkan oleh manusia untuk menyampaikan isi hatinya kepada manusia lainnya.

Dalam Kamus Besar Bahasa Indonesia (Depdikbud, 1991) bahasa bermakna: 1) sistem lambing yang arbitrer, yang dipergunakan oleh para anggota suatu masyarakat untuk kerjasama, berinteraksi dan mengidentifikasi diri. 2) percakapan (peralatan), yang baik, tingkah laku yang baik, sopan santun.

Berdasarkan telaah pendapat ahli, dapat disimpulkan bahwa bahasa merupakan alat komunikasi antar anggota masyarakat, yang berupa bunyi, yang dihasilkan oleh alat ucap manusia.

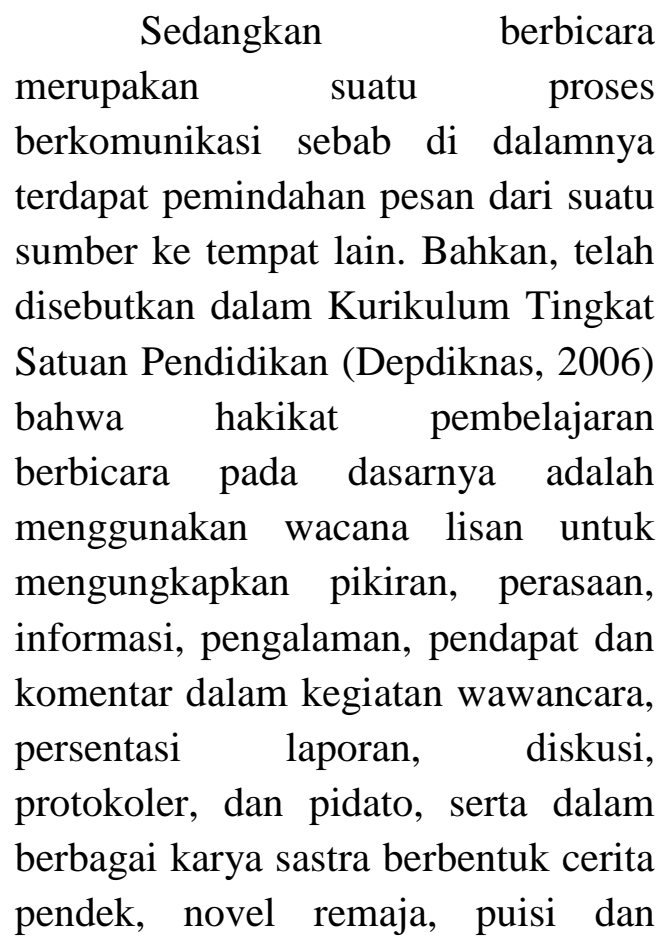

drama (KBBI, 2005). Berbicara adalah beromong, bercakap, berbahasa, mengutarakan isi pikiran, melisankan sesuatu yang dimaksudkan.

Jadi, dapat disimpulkan bahwa berbicara merupakan kegiatan penyampaian maksud, ide, gagasan, dan pikiran kepada orang lain secara lisan yang berhubungan dengan artikulasi/kejelasan dalam berkomunikasi yang dihasilkan oleh alat ucap manusia yang melibatkan mental motorik.

Setiap kegiatan yang di kerjakan dan dilakukan oleh manusia pasti memiliki makna dan tujuan, begitu pula dengana kegiatan berbicara memiliki tujuan agar pembicara mendapat respon atau reaksi tertentu. Tujuan pembicaraan sangat tergantung pada keadaan dan keinginan pembicara. Maidar G. Arsjad, dkk (1993) mengatakan tujuan utama berbicara adalah untuk berkomunikasi. Dengan berkomunikasi pembicara dapat menyampaikan pembicaraan secara efektif, sebaiknya pembicara betulbetul memahami isi pembicaraannya.

\section{Menurut Sabarti Akhadiah} (2008) pada dasarnya, tujuan berbicara adalah mendorong atau menstimulasi, meyakinkan, menggerakkan, menginformasikan, dan menghibur. Adapun pengertian yang lebih rinci dari tujuan yang telah disebutkan di atas yaitu: 
a. Mendorong atau Menstimulasi

Berbicara untuk mendorong atau menstimulasi pendengar jauh lebih kompleks dari tujuan berbicara lainnya, sebab berbicara itu harus pintar merayu, mempengaruhi, atau meyakinkan pendengarnya.

\section{b. Meyakinkan}

Berbicara yang baik, pembicara berusaha meyakinkan pendengar, agar pendengar yakin bahwa yang menjadi bahan pembicaraan dapat dipahami dan informasi yang disampaikan oleh pembicara dapat tersampaikan.

\section{c. Menggerakkan}

Dalam berbicara untuk menggerakkan diperlukan pembicara yang berwibawa, panutan atau tokoh idola masyarakat. Melalui kepintarannya dalam, kecakapan memanfaatkan situasi, pembicara dapat menggerakkan pendengarnya.

\section{d. Menginformasikan}

Berbicara untuk tujuan menginformasikan, hal ini dilakukan oleh pembicara dengan maksud ingin menjelaskan suatu proses, menguraikan, menafsirkan, atau mengintepretasikan sesuatu hal, memberi, menyebarkan, atau menanamkan pengetahuan, dan menjelaskan kaitan.

\section{e. Menghibur}

Berbicara untuk menghibur berarti pembicara menarik perhatian dengan berbagai cara, seperti cerita humor, spontanitas, menggairahkan, kisah-kisah jenaka, petualangan, dan sebagainya untuk menimbulkan suasana gembira.

Mengacu teori tersebut, maka berbicara memiliki tujuan yang tergantung pada kondisi dan keinginan pembicara. Pembicara sebaiknya memahami makna segala sesuatu yang ingin disampaikan, agar pembicara mendapatkan responn dari pendengar atau penyimak agar tujuannya dapat tercapai.

$$
\text { Agar tujuan keterampilan }
$$
berbicara dapat tercapai dengan baik, sebaiknya siswa memperhatikan faktor-faktor keterampilan berbicara dengan teliti. Faktor-faktor tersebut Menurut Ahmad Rofi'uddin dan Darmiyati Zuhdi (1998) dalam berbicara merupakan bentuk perilaku manusia yang memanfaatkan faktorfaktor berikut ini.

a. Seseorang memanfaatkan faktor fisik yaitu alat ucap untuk menghasilkan bunyi serta organ tubuh seperti kepala, tangan, dan roman atau mimik muka.

b. Faktor psikologis mempunyai pengaruh yang sangat besar terhadap kelancaran dan kefasihan dalam berbicara. Emosi yang setabil akan berpengaruh terhadap kualitas suara yang dihasilkan oleh alat ucap dan berpengaruh juga 
terhadap keruntutan bahan pembicaraan, apakah seseorang berbicara dengan tertata atau tidak.

c. Faktor neurologis, yaitu jaringan saraf yang menghubungkan otak kecil dengan mulut, telinga, dan organ tubuh lain yang ikut dalam aktivitas berbicara.

d. Faktor semantik atau makna dan faktor linguistik yaitu struktur bahasa yang digunakan.

\section{Muhadjir}

mengungkapkan beberapa faktor penunjang pada kegiatan berbicara antara lain sebagai berikut:

a. Faktor Kebahasaan

Faktor kebiasaan ini mencangkup beberapa hal antara lain:

1. Ketepatan ucapan

2. Penepatan tekanan nada sendi atau durasi yang sesuai

3. Pilihan kata

4. Ketepatan penggunaan kalimat serta tata bahasanya

5. Ketepatan sasaran pembicaraan.

b. Faktor Non Kebahasaan

Faktor non kebiasaan ini meliputi:

1. Sikap yang wajar

2. Tenang dan tidak kaku

3. Pandangan harus diarahkan ke lawan bicara

4. Kenyaringan suara

5. Kelancaran

6. Relevansi/penalaran

7. Penguasaan topik.
Berdasarkan itu, siswa perlu

memanfaatkan faktor-faktor keterampilan berbicara seperti fisik, psikologis, neurologis, semantik, linguistik, kebahasaan dan non kebahasaan dengan baik. Selain faktor tersebut peranan orang tua juga memiliki peranan yang penting dalam proses bahasa anak. Anak yang dapat memanfaatkan faktor-faktor tersebut dengan optimal, maka keterampilan berbicaranya akan tercapai dengan baik. Dalam penelitian ini peneliti menggunakan model pembelajaran Picture and Picture.

Model pembelajaran Picture and Picture merupakan model pembelajaran yang dalam prosesnya, guru menggunakan media gambar sebagai media pembelajaran. Menurut Suprijono (2014), model Picture and Picture merupakan salah satu strategi pembelajaran yang menggunakan gambar sebagai media dalam pembelajaran untuk membantu siswa menguasai materi pelajaran. Suprijono beranggapan bahwa Picture and Picture mampu meningkatkan skill-skill dasar, pencapaian interaksi positif antar siswa, harga diri, dan sikap penerimaan pada siswa-siswa lain yang berbeda. Tambahan penjelasan mengenai itu, Zaenal (2015), model Picture and Picture adalah model pembelajaran yang ditekankan pada gambar yang diurutkan menjadi urutan yang logis.

Berdasarkan telaah pendapat ahli, maka disimpulkan bahwa model 
Picture and Picture merupakan model pembelajaran yang penerapannya dengan menggunakan media gambar. Hal ini untuk membantu siswa menguasai materi pelajaran yang harus dicapai. Melalui model pembelajaran Picture and Picture ini, siswa akan mengasah kemampuan berpikirnya melalui proses mengurutkan gambar menjadi urutan yang logis.

Menurut Suprijono (2013), langkah-langkah pembelajaran model Picture and Picture sebagai berikut:

Tahap 1: Penyampaian Kompetensi

Pada tahap ini, guru diharapkan menyampaikan kompetensi dasar mata pelajaran yang bersangkutan.

\section{Tahap 2: Persentasi Materi}

Pada tahap penyajian materi, guru telah menciptakan momentum awal pembelajaran dengan memberikan motivasi kepada siswa.

Tahap 3: Penyajian Gambar

Pada tahap ini, guru menyajikan gambar dan mengajak siswa untuk terlibat proses pembelajaran dengan mengamati setiap gambar yang ditunjukkan.

\section{Tahap 4: Pemasangan Gambar}

Pada tahap ini, guru menunjuk atau memanggil siswa secara bergantian untuk memasang gambargambar secara berurutan dan logis.
Tahap 5: Penjajakan

Tahap ini mengharuskan guru menanyakan kepada siswa tentang alasan atau dasar pemikiran dibalik urutan gambar yang disusunnya (umpan balik).

Tahap 6: Penyajian Kompetensi

Tahap ini guru bisa mengulangi, menuliskan, atau menjelaskan sesuai gambar-gambar yang telah diurutkan.

Tahap 7: Penutup

Di akhir pembelaJjaran, guru dan siswa melakukan refleksi mengenai apa yang telah dicapai dan dilakukan.

\section{METODE PENELITIAN}

Jenis penelitian ini merupakan penelitian tindakan kelas (PTK) yang dilaksanakan pada semester II tahun pelajaran 2015/2016. Subjek penelitian ini dilakukan pada siswa kelas 5 SDN Mangunsari 03 Salatiga yang jumlahnya sebanyak 38 dengan 18 anak laki-laki dan 20 anak perempuan. Obyek yang ditangani dalam penelitian ini adalah kemampuan berbicara anak dengan menggunakan model pembelajaran picture and picture.

Penelitian ini mengacu pada teorinya kemis dan Mc.Taggart dengan menggunakan dua siklus, masing-masing siklus terdiri dari tiga tahap yaitu perencanaan tindakan, 
pelaksanaan tindakan, observasi dan refleksi.

Tahap pertama, yaitu perencanaan yang di lakukan adalah menyiapkan materi, menyusun RPP, menyiapkan media gambar, lembar observasi kegiatan belajar mengajar guru dan siswa dengan menggunakan model picture and picture.

Tahap kedua, peneliti melakukan tindakan seusai dengan rancangan pembelajaran yang sudah dibuat, yaitu pembelajaran Bahasa Indonesia menggunakan model picture and picture.

Tahap ketiga observasi dan ferleksi, tahap observasi yang dilakukan untuk mengetahui kegiatan yang dilakukan guru dan siswa selama kegiatan pembelajaran keterampilan berbicara menggunakan model picture and picture berlangsung. Refleksi dilakukan untuk mengkaji hasil penelitian terhadap pelaksanaan terhadap pelaksanaan tindakan tersebut, dan jika terjadi kendala akan dicari pemecahan masalah untuk direncanakan tindakan pada siklus selanjutnya.

Variabel dalam penelitian ini ada dua yaitu variabel bebas dan variabel terikat. Variabel bebas dalam penelitian ini adalah penerapan model pembelajaran Picture and Picture. Sedangkan variabel terikat dalam penelitian ini adalah keterampilan berbicara siswa kelas 5 SD Negeri Mangunsari 03 Salatiga. Teknik pengumpulan data pada penelitian ini bersumber dari observasi, tes, wawancara, dan dokumentasi.

Penelitian ini menggunakan teknik analisis deskriptif kualitatif. Teknik data dalam penelitian ini dilihat dari angket data proses dan analisis data hasil/produk. Analisis data secara proses diambil pada waktu pelaksanaan pembelajaran keterampilan berbicara siswa dengan menggunakn model pembelajaran picture and picture. Analisis data secara hasil/produk diambil dari hasil penilaian keterampilan berbicara pada masing-masing siswa saat melakukan praktik berbicara didepan kelas dengan menggunakan gambar. Kemampuan keterampilan berbicara siswa dinilai dengan pedoman penilaian yang sudah di tentukan.

\section{HASIL DAN PEMBAHASAN}

Pada bagian ini akan dipaparkan hasil penelitian mengenai keterampilan berbicara siswa dengan menggunakan model pembelajaran picture and pictute pada kelas $5 \mathrm{SD}$ Negeri Mangunsari 03 Salatiga. Setelah melaksanakan kegiatan analisis terhadap 2 siklus yang telah dilaksanakan, maka dapat disimpulkan bahwa penggunaan model pembelajaran picture and picture pada kelas 5 SDN Mangunsari 03 salatiga, menunjukkan peningkatan keterampilan berbicara. Peningkatan tersebut akan dipaparkan pada tabel 1 dan grafik 1 . 
Tabel 1. Rekapitulasi Peningkatan

Keterampilan Berbicara Siswa

Prasiklus, Siklus I, dan Siklus II

\begin{tabular}{|c|c|c|c|c|c|}
\hline No & Aspek & $\begin{array}{l}\text { Rerata } \\
\text { Skor } \\
\text { Pratinda } \\
\text { kan }\end{array}$ & $\begin{array}{l}\text { Rerata } \\
\text { Skor } \\
\text { Siklus I }\end{array}$ & $\begin{array}{c}\text { Rerata } \\
\text { Siklus } \\
\text { II }\end{array}$ & $\begin{array}{r}\text { Pening } \\
\text { katan }\end{array}$ \\
\hline 1 & Tekanan & 2.5 & 3.10 & 3.5 & 1 \\
\hline 2 & Ucapan & 2.5 & 2.81 & 3.23 & 0.73 \\
\hline 3 & $\begin{array}{l}\text { Kosakata/ } \\
\text { Diksi }\end{array}$ & 2.25 & 2.89 & 3.28 & 1.03 \\
\hline 4 & $\begin{array}{l}\text { Struktur } \\
\text { Kalimat }\end{array}$ & 2.42 & 2.89 & 3.21 & 0.79 \\
\hline 5 & Kelancaran & 2.52 & 2.89 & 3.23 & 0.71 \\
\hline 6 & $\begin{array}{l}\text { Pengungka } \\
\text { pan Meteri } \\
\text { Berbicara }\end{array}$ & 2.47 & 2.86 & 3.21 & 0.74 \\
\hline 7 & Sikap & 2.63 & 2.92 & 3.23 & 0.6 \\
\hline 8 & Keberanian & 2.68 & 2.97 & 3.28 & 0.6 \\
\hline & $\begin{array}{l}\text { lah rata-rata } \\
\text { hitung }\end{array}$ & 19.97 & 23.33 & 26.17 & 6.2 \\
\hline
\end{tabular}

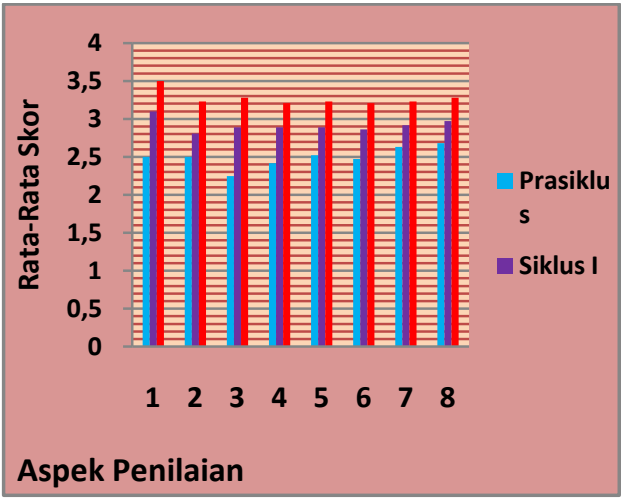

Gambar 1. Grafik Peningkatan Hasil

Perskoran Aspek-Aspek Keterampilan

Berbicara Siswa Pratindakan Sampai

Siklus II.

\section{Keterangan:}

Angka 1: Tekanan

Angka 2: Ucapan

Angka 3: Kosakata/Diksi

Angka 4: Struktur Kalimat

Angka 5: Kelancaran

Angka 6: Pengungkapan Materi
Angka 7: Sikap

Angka 8: Keberanian

Berdasarkan pada Tabel 1 dan Gambar 1, dapat diketahui skor tes keterampilan berbicara siswa dengan menggunakan model pembelajaran picture and picture mengalami peningkatan. Rata-rata prasiklus yang tadinya sebesar 19.97, menjadi 23.33 setelah diberi tindakan pada siklus I, dan pada siklus II meningkat menjadi 26.17. Kenaikan skor rata-rata mulai darai prasiklus hingga siklus II mengalami peningkatan sebesar 6.2. Pada peningkatan setiap aspek dari siklus prasiklus ke siklus II yang menggalami peningkatan paling tinggi anata lain pada aspek kosakata/diksi meningkat sebesar 1.03. Sedangkan aspek keterampilan berbicara yang meningkat paling sedikit antara lain pada aspek sikap dan keberanian yaitu 0,6.

\section{Pembahasan}

$\begin{array}{rrr}\text { Pada } & \text { penelitian } & \text { ini, } \\ \text { pembahasan } & \text { difokuskan }\end{array}$ pelaksanaan tindakan kelas dalam pembelajaran keterampilan berbicara, dan peningkatan keterampilan berbicara siswa dengan menggunakan model pembelajaran Picture and Picture.

Berdasarkan pelaksanaan siklus I tersebut peneliti melihat bahwa masih perlu dilakukan perbaikan pada siklus II untuk meningkatkan setiap aspek secara 
maksimal, namun peneliti mengfokuskan pelaksanaan pada siklus II ini pada aspek sikap dan keberanian karena pada aspek inilah rata-ratannya tergolong rendah jika dibandingkan dengan aspek-aspek yang lain. Setelah dilakukan siklu II ini semua aspek-aspek pembelajaran keterampilan berbicara siswa mengalami peningkatan, sehingga mencapai indikator keberhasilan yang sudah ditetapkan oleh peneliti.

Sehingga

peneliti menyimpulkan dengan menggunakan model pembelajaran Picture and Picture untuk meningkatkan keterampilan berbicara siswa mampu membuat suasana kelas yang tadinya pasif menjadi lebih aktif, yang tadinya pembelajaran membosankan menjadi menyenagkan,dan siswa terlihat sangat antusias ketika memperhatikan guru menampilkan gambar-gambar pembelajaran dan terlihat juga ketika siswa maju kedepan kelas untuk menempelkan gambar pembelajaran siswa terlihat berebut dengan temannya.

Berdasarkan hasil angket pascatindakan menunjukkan bahwa 38 siswa dari keseluruhan jumlah siswa pada kelas $\mathrm{V}$ menyatakan dengan menggunakan model Picture and Picture pembelajarn menjadi menyenangkan, memberikan kesan positif, dan siswa menjadi percaya diri ketika berbicara didepan kelas.

Penilaian keterampilan berbicara siswa dilakukan dengan

masing-masing siswa ketika siswa berbicara didepan kelas. Penilaian keterampilan berbicara dilakukan untuk mengukur rata-rata skor keterampilan berbicara siswa sebelum dan sesudah pemberian tindakan. Peningkatan keterampilan berbicara siswa dari prasiklus hingga siklus II dapat dilihat pada Gambar 2.

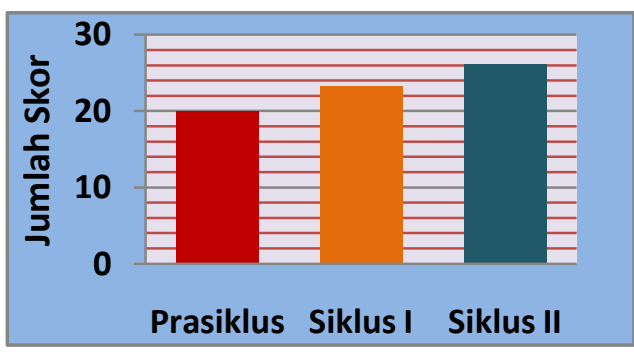

\section{Gambar 2. Grafik Peningkatan Keterampilan Berbicara Siswa Dari Prasiklus Sampai Siklus II}

Berdasarkan gambar 2 terlihat adanya peningkatan yang signifikan dari prasiklus, siklus I, dan siklus II. Sebelum dikenai tindakan skor ratarata siswa yaitu 19.97, setelah diberi tindakan siklus I meningkat menjadi 23.33, dan pada siklus II meningkat menjadi 26.17. peningkatan skor ratarata keterampilan berbicara dari prasiklus hingga siklus II adalah sebesar 6.2.

Berikut akan dijelaskan peningkatan keterampilan berbicara siswa jika dilihat pada masing-masing aspek yang harus dicapai.

1. Tekanan

\begin{tabular}{ccr} 
Aspek & tekanan pada \\
pembelajaran & \multicolumn{2}{c}{ keterampilan } \\
berbicara ini & berkaitan dengan
\end{tabular}


penekanan pada tinggi-rendahnya, keras-lambatnya ketika berbicara pada kata yang dianggapnya penting. Aspek tekanan siswa pada prasiklus pada kategori cukup baik dengan skor rata-rata sebesar 2.1. pada siklus I skor rata-rata meningkat menjadi 3.10 dengan kategori baik, dan pada siklus II skor rata-rata meningkat menjadi 3.5 dengan kategori sangat baik. Pada aspek ini jumlah peningkatan dari prasiklus hingga siklus II sebesar 1.

2. Ucapan

Aspek ucapan pada pembelajaran keterampilan berbicara ini berkaitan dengan kerampilan siswa dalam menuturkan bahasa dengan benar dan tidak dicampur dengan bahasa daerah setempat. Aspek ucapan siswa pada prasiklus pada kategori cukup baik dengan skor rata-rata sebesar 2.5, pada siklus I skor ratarata meningkat menjadi 2.81 dengan kategori baik, dan pada siklus II skor rata-rata meningkat menjadi 3.23 dengan kategori baik. Pada aspek ini jumlah peningkatan dari prasiklus hingga siklus II sebesar 0.73 .

\section{Kosakata/Diksi}

Aspek kosakata/diksi pada pembelajaran keterampilan berbicara ini berkaitan dengan keterampilan siswa dalam menggunakan kosakata dengan baik dan benar. Aspek kosakata/diksi siswa pada prasiklus pada kategori cukup baik dengan skor rata-rata sebesar 2.25, pada siklus I skor rata-rata meningkat menjadi 2.89 dengan kategori baik, dan pada siklus II skor rata-rata meningkat menjadi 3.28 dengan kategori baik. Pada aspek ini jumlah peningkatan dari prasiklus hingga siklus II sebesar 1.03 .

\section{Struktur Kalimat}

Aspek struktur kalimat pada pembelajaran keterampilan berbicara ini berkaitan dengan keterampilan siswa dalam mengucapkan struktur kalimat yang jelas dan tepat. Aspek struktur kalimat siswa pada prasiklus pada kategori cukup baik dengan skor rata-rata sebesar 2.42, pada siklus I skor rata-rata meningkat menjadi 2.89 dengan kategori baik, dan pada siklus II skor rata-rata meningkat menjadi 3.21 dengan kategori baik. Pada aspek ini jumlah peningkatan dari prasiklus hingga siklus II sebesar 0.79 .

\section{Kelancaran}

Aspek struktur kalimat pada pembelajaran keterampilan berbicara ini berkaitan dengan keterampilan siswa menceritakan isi gambar menggunakan bahasa 
Indonesia yang benar dan secara lancar. Pengungkapan Materi Berbicara. Aspek kelancaran siswa pada prasiklus pada kategori cukup baik dengan skor rata-rata sebesar 2.52, pada siklus I skor rata-rata meningkat menjadi 2.89 dengan kategori baik, dan pada siklus II skor rata-rata meningkat menjadi 3.23 dengan kategori baik. Pada aspek ini jumlah peningkatan dari prasiklus hingga siklus II sebesar 0.71 .

6. Pengungkapan Materi Berbicara Aspek struktur kalimat pada pembelajaran keterampilan berbicara ini berkaitan dengan keterampilan siswa dalam mengungkapkan materi berbicara sesuai dengan isi gambar. Aspek kelancaran siswa pada prasiklus pada kategori cukup baik dengan skor rata-rata sebesar 2.47, pada siklus I skor rata-rata meningkat menjadi 2.86 dengan kategori baik, dan pada siklus II skor rata-rata meningkat menjadi 3.21 dengan kategori baik. Pada aspek ini jumlah peningkatan dari prasiklus hingga siklus II sebesar 0.74 .

7. Sikap

Aspek struktur kalimat pada pembelajaran keterampilan berbicara ini berkaitan dengan keterampilan siswa dalam menunjukkan sikap wajar ketika berbicara didepan kelas, siswa

berdiri tegap dan tidak mainan tangan atau kakinya. Aspek kelancaran siswa pada prasiklus pada kategori baik dengan skor rata-rata sebesar 2.63, pada siklus I skor rata-rata meningkat menjadi 2.97 dengan kategori baik, dan pada siklus II skor rata-rata meningkat menjadi 3.28 dengan kategori baik. Pada aspek ini jumlah peningkatan dari prasiklus hingga siklus II sebesar 0.6.

\section{Keberanian}

Aspek struktur kalimat pada pembelajaran keterampilan berbicara ini berkaitan dengan keterampilan siswa dalam berbicara lisan di depan kelas dengan jelas dan tanpa ada rasa malu/grogi. Aspek kelancaran siswa pada prasiklus pada kategori baik dengan skor rata-rata sebesar 2.68, pada siklus I skor rata-rata meningkat menjadi 2.97 dengan kategori baik, dan pada siklus II skor rata-rata meningkat menjadi 3.28 dengan kategori baik. Pada aspek ini jumlah peningkatan dari prasiklus hingga siklus II sebesar 0.6.

Pengamatan proses yang
dilakukan guru ketika proses
pembelajaran berlangsung dapat dilat
melalui lembar observasi kegiatan
guru yang dilakukan oleh observer.
Peningkatan tersebut dapat dilihat
ketika guru mengajar dengan


menggunakan model Picture and Picture guru sudah melakukan pembelajaran Picture and Picture dengan baik, guru juga sudah mendorong siswa untuk ikut berperan aktif dalam pembelajaran ini.

Sedangkan pengamatan proses yang dilakukan siswa ketika proses pembelajaran berlangsung dapat dilihat melalui lembar observasi kegiatan siswa yang dilakukan oleh observer. Peningkatan tersebut dapat dilihat ketika proses pembelajaran keterampilan berbicara dengan menggunakan model pembelajaran Picture and Picturesiswa merasa aktif, menyenagkan dan tidak membosankan. Dengan menggunakan model Picture and Picturesiswa juga merasa mudah ketika berbicara didepan kelas, tidak merasa malu dan takut lagi.

\section{SIMPULAN}

Berdasarkan hasil analisis Penelitian Tindakan Kelas (PTK) siklua I dan siklus II memberikan gambaran bahwa dengan menggunakan model pembelajaran picture and picture terhadap keterampilan berbicara siswa dapat meningkat. Hal tersebut dapat dilihata pada hasil observasi pengamatan proses dan hasil observasi pengamatan produk/hasil.

Hasil observasi pengamatan proses. Pembelajarannya siswa mengalami peningkatan yang tercermin dalam antusia siswa dalam mengikuti pembelajaran dan antusias siswa ketika diminta maju kedepan kelas untuk berbicara. Kegiatan belajar siswa menjadi lebih aktif, komunikatif, dan menyenangkan.

Lembar pengamatan

keterampilan berbicara siswa secara hasil diperoleh dari penilaian berbicara siswa didepan kelas pada setiap akhir siklus. Skor rata-rata siswa sebelum dikenakan tindakan sebesar 19.97, skor rata-rata siswa setelah dikenai tindakan pada siklus I meningkat sebesar 3.36 menjadi 23.33. sekor rata-rata pada akhir tindakan siklus II mengalami peningkatan sebesar 2.84, rataratannya menjadi 26.17. Peningkatan

Bagi guru, melalui pengalaman dalam menerapkan model pembelajaran Picture and Picture guru dapat mengembangkan pembelajaran dengan lebih kreatif. Dengan menciptakan suasana pembelajaran dikelas yang menyenagkan dan dapat membantu peserta didik dalam memahami materi pembelajaran. Sehingga perlu digunakan model pembelajaran yang bervariasi untuk meningkatakan proses dan hasil belajar siswa.

\section{DAFTAR RUJUKAN}

Arsqad Mukti, midar G (2013), Pembiaan Kemampuan Berbicara Bahasa Indonesia, Jakarta: Erlangga.

Depdikbud. 2001. Kamis Besar Bahasa Indonesia. Jakarta: Depdikbud. 
Febry Damai Riyanti: Peningkatan Keterampilan ..

Henry Guntur Tarigan. (2008). Berbicara Sebagai Satu Keterampilan Berbahasa. Bandung: Angkasa Bandung.

Huda, Miftahul. 2013. Model-Model Pengajaran dan Pembelajaran. Yogyakarta: Putaka Pelajar.

Prof. Dr. Achmad H. P dan Dr. Alek, M.pd. (2016). Bahasa Indonesia Untuk Perguruan Tinggi. Penerbit: Erlangga.

Soyem. (2015). Upaya Meningkatkan Hasil Belajar Siswa Melalui Penerapan Model Pembelajaran Picture And Picture Pada Mata Pelajaran PKN Siswa SD Negeri 105300 Suka Makmutr. Elementary School Jurnal Pgsd Fkip Unimed 3 (2).
St, Y.Slamet. 2007. Dasar-dasar keterampilan Berbahasa Indonesia. Surakarta: UNS Press.

Suprijono. 2009. Cooperative Learnig. Yogyakarta: Pustaka Pelajar.

Suharsimi Arikunto, Suharjono dan Supardi. 2006. Penelitian Tindakan Kelas. Yogyakarta: Bumi Aksara. 